\title{
Performance of juice and wine grape cultivars in different training systems
}

\author{
Mário José Pedro Júnior ${ }^{1}$, José Luiz Hernandes ${ }^{2}$, Mara Fernandes Moura ${ }^{3}$ \\ Abstract - The increase of rural tourism activities has led growers to use different grape cultivars for \\ the production of wine and/or juice. Thus, the aim of this study was to evaluate the phytotechnical \\ characteristics of grapevines and physicochemical characteristics of grape must obtained for Bordô, \\ Isabel Precoce, BRS Violeta, Isabel and Concord cultivars in different training systems: vertical \\ shoot position; Y-shaped trellis and V-shaped trellis with double spur cordon. The experimental \\ design was randomized blocks for comparison of cultivars within each training system and analysis \\ of the main components for productivity variables was carried out. BRS Violeta cultivar showed \\ higher bunch weight values regardless of training system. Bordô cultivar showed lower yield values \\ and soluble solids content in comparison to other cultivars. Isabel and Isabel Precoce cultivars in \\ the evaluated training systems showed higher soluble solids content. Principal component analysis \\ allowed verifying that in Y-shaped trellis and V-shaped trellis with double spur cordon training \\ systems, cultivars were related to higher yield. \\ Index terms: grapevine, rustic grape, yield, soluble solids.

\section{Desempenho de cultivares de uva para suco e vinho em diferentes sistemas de sustentação}

Corresponding author: mariopedrojunior@gmail.com

Received: May 14, 2018

Accepted: August 07, 2018

Copyright: All the contents of this journal, except where otherwise noted, is licensed under a Creative Commons Attribution License.

\begin{abstract}
Resumo - O crescimento das atividades do turismo rural tem levado os viticultores a utilizarem diferentes cultivares de uva para elaboração de vinho e/ou suco. Nesse sentido, objetivou-se avaliar as características fitotécnicas das videiras e físico-químicas do mosto das cultivares Bordô, Isabel Precoce, BRS Violeta, Isabel e Concord, em diferentes sistemas de sustentação: espaldeira; manjedoura na forma de $\mathrm{Y}$ e manjedoura na forma de $\mathrm{V}$ com cordão esporonado duplo. O delineamento experimental foi em blocos ao acaso para a comparação das cultivares, dentro de cada sistema de sustentação, e foi realizada análise dos componentes principais para as variáveis da produção. A cultivar BRS Violeta apresentou maior massa de cacho, independentemente do sistema de sustentação das videiras. A cultivar Bordô foi a menos produtiva e com menor teor de sólidos solúveis, em comparação com as outras cultivares. As cultivares Isabel e Isabel Precoce, nos sistemas de sustentação avaliados, apresentaram maior teor de sólidos solúveis. A análise de componentes principais permitiu verificar que os sistemas manjedoura na forma de $\mathrm{Y}$ e $\mathrm{V}$ com cordão esporonado duplo foram associados a maiores produtividades.
\end{abstract}

Termos de indexação: videira, uva rústica, produtividade, sólidos solúveis.

${ }^{1} \mathrm{PhD}$, Scientific Researcher - Instituto Agronômico de Campinas - Centro de Solos e Recursos Ambientais, Campinas, São Paulo, Brasil. E-mail: mariopedrojunior@gmail.com

${ }^{2} \mathrm{MSc}$, Scientific Researcher - Instituto Agronômico de Campinas, Centro de Frutas. Jundiaí, São Paulo, Brasil. E-mail: jlhernandes@iac. sp.gov.br

${ }^{3}$ PhD., Scientific Researcher - Instituto Agronômico de Campinas, Centro de Frutas, Jundiaí, São Paulo, Brasil. E-mail: mara.fernandes.moura@ gmail.com 


\section{Introduction}

The development of rural tourism has allowed wine growers in the region of Jundiaí additional source of income from the sale of fresh grapes and / or handcrafted with juice / wine production (Verdi et al., 2011). Due to the high cost of hand and increasing difficulty in labor availability, winegrowers need to adjust by intensifying the search for cultivars and more productive training systems for grapevines.

Regarding cultivars and hybrids most used in juice / wine production, it is possible to observe that in the region of Jundiaí (SP), 'Niagara' and 'Bordô' stand out because they are adapted to the climatic conditions of the region while Isabel cultivar is more commonly found in Southern Brazil (CAMARGO et al., 2011).

"Isabel" cultivar has been the basis of the production of Brazilian grape juice for export, being mainly used in Rio Grande do Sul. In turn, Isabel Precoce cultivar, which is a somatic mutation of Isabel cultivar, presents the same characteristics of the original cultivar, except for the cycle, being more precocious. Its precocity contributes to the enlargement of the grape harvest and processing period in the Southern region and in tropical regions, with production of up to two harvests (CAMARGO et al., 2010).

Bordô cultivar, in addition to the rusticity of vines, presents the possibility of elaboration of full bodied and foxy juice / wine, with good acceptance by the consumer (TECCHIO et al., 2007). In relation to Concord cultivar, it was found that it is a variety of Vitis labrusca very popular in North American and Brazilian viticulture due to the organoleptic characteristics, being important in the juice industry (CAMARGO et al., 2010) and recommended for region of Serra Gaúcha and western region of Santa Catarina State, presenting potential of cultivation in regions with subtropical climate.

BRS Violeta cultivar reaches solids content between 19 and $21^{\circ}$ Brix and has high fertility, which results in high productive capacity, reaching 25 to 30 tha $^{-1}$ (CAMARGO et al., 2010) and presents certain precocity (APARECIDO et al., 2017).

In relation to the training system of vines, it was verified that winemakers of the producing region of Jundiai (SP) mainly use the vertical shoot position (VSP) training system with bilateral single cordon.

Training systems in modern winemaking have adapted to a reality of use in intensive crops and severe pruning to increase the producer's income. The manger system allows the conduction of V-shaped branches, allowing greater exposure of leaves and protecting bunches against excess sunlight. To increase productivity, a combination of manger system with the use of double spur cordon was performed for Niagara Rosada cultivar, resulting in $75 \%$ increase in production compared to the
VSP system (PEDRO JUNIOR et al., 2007).

In the search for training systems more adapted to modern viticulture, producers have used Y-shaped trelis, which has had its use encouraged in Santa Catarina and currently in Rio Grande do Sul (CHAVARRIA et al., 2009) and in São Paulo (PEDRO JÚNIOR, et al., 2011; HERNANDES and PEDRO JÚNIOR, 2015). Pedro Júnior et al. (2011) verified for Niagara Rosada cultivar in the State of São Paulo, that the productivity in the Y-shaped system was superior to that of the VSP system and also presented better bunch quality, providing greater profitability to winegrowers. The Y-shaped training system, although with higher initial implantation cost, offers advantages such as: reduction of the need for tying branches, almost horizontal conduction of branches, reducing the formation of adventitious sprouts and increasing the efficiency of phytosanitary treatment; facilitated circulation in the vineyard and reduction of labor (HERNANDES and PEDRO JÚNIOR, 2015).

Therefore, in order to characterize different grape cultivars for the elaboration of juice and wine, managed in different training systems, an experiment was carried out in the region of Jundiaí (SP) to evaluate: productive behavior and grape must quality in vineyards with Isabel Precoce, Bordô, BRS Violeta, Isabel and Concord cultivars using the following training systems: VSP; V-shaped trellis with double spur cordon and Y-shaped trellis.

\section{Material and methods}

The experiment was carried out in a vineyard with Isabel Precoce, Bordô, BRS Violeta, Concord and Isabel grape cultivars at the "Centro de Frutas" of the Instituto Agronômico de Campinas (IAC/APTA/SAA) located in Jundiaí (2312'S: $46^{\circ} 53^{\prime} \mathrm{W}$ and $715 \mathrm{~m}$ a.s.1.). According to Koeppen's classification, the climate of the region is Cfa. The training systems evaluated were: vertical shoot position system (VSP) with single spur cordon; V-shaped trellis with double spur cordon (CD) as described in Pedro Júnior et al. (2007), and Y-shaped trellis with single spur cordon (Y). The experimental area consisted of 12 rows of $30 \mathrm{~m}$ in length, being four rows for each training system. The design was randomized blocks within each training system with four treatment replicates (cultivars). Experimental plots were composed of six plants arranged between two posts, and the four central plants were considered for sampling. The spacing between rows was $2 \mathrm{~m}$ and between plants $1 \mathrm{~m}$ and grape cultivars were grafted on IAC 572 'Jales' rootstock.

The experiment was evaluated during the 2013, 2014 and 2015 growing seasons, with short winter pruning leaving two buds per branch in the first half of August. Sprouting stimulation was performed using 3.5\% Dormex ${ }^{\circledR}$ and phytosanitary treatments to control major 
fungal diseases; management of vines (winter pruning, adventitious sprouts removal, tendril removal, shoot topping) and fertilization were performed according to technical recommendation for the region.

Harvest was carried out from December to January, and the following characteristics were evaluated in each experimental plot: number of shoots per plant; fresh bunch weight $(\mathrm{g})$; number of bunches per plant and for productivity estimation, the average production per plant was multiplied by the number of plants per hectare, the result being expressed in $\mathrm{tha}^{-1}$. The following grape must physicochemical parameters were also evaluated: soluble solids - SS ( ${ }^{\circ}$ Brix); titratable acidity - TA $\left(\mathrm{mEq} \mathrm{L}^{-1}\right)$ and total soluble solids and tartaric acid content (\%) - Ratio. The evaluation of the physicochemical characteristics of grape must was made by collecting 80 berries in each experimental plot, located in the basal, median and apical zones of different bunches and subdivided into four subsamples for analysis. The soluble solids content (SS) after the crushing of berries was determined by digital refractometer (Atago-mod. PAL-3) and the result was expressed in ${ }^{\circ}$ Brix. Titratable acidity was obtained by titration of the juice with a standard solution of $0.1 \mathrm{~N}$ $\mathrm{NaOH}$, with titration endpoint at $\mathrm{pH}=8.2$ using a digital benchtop $\mathrm{pH}$ meter (Digimed). Maturation index was obtained by the soluble solids content / tartaric acid content ratio (TAC) expressed as percentage.

Data from each cultivar, in each training system, were submitted to analysis of variance and the means were compared by the Tukey test at $5 \%$ of probability error. Principal component analysis was also performed for the following parameters: yield, number of bunches, number of shoots and bunch fresh weight of cultivars evaluated in the different training systems.

\section{Results and discussion}

Table 1 shows the values of the phytotechnical variables and physicochemical characteristics of grape must for cultivars in VSP, Y-shaped trellis and V-shaped with double spur cordon training systems.

Bunch fresh weight - In the VSP training system, the highest fresh weight was obtained for BRS Violeta cultivar (164.1g), significantly differing from Isabel, Bordô and Isabel Precoce cultivars. These values were similar to those reported by Ribeiro (2013) for the region of Jundiaí-SP $(157.7 \mathrm{~g})$. On the other hand, Bordô cultivar showed the lowest bunch fresh weight value (93.3g) similar to that obtained by Chiarotti et al. (2011) for Bocaiuva do Sul-PR. For Isabel Precoce, Isabel and Concord cultivars, intermediate bunch fresh weight values were obtained, ranging from 126 to $148.4 \mathrm{~g}$. Bunch fresh weight were similar to those reported in literature for Isabel cultivar (SANTOS et al, 2011; SATO et al., 2009; RIZZON and MIELE, 2006) and higher than those found for Concord cultivar (ANZANELLO et al., 2008; BORGES et al., 2014).

Considering the Y-shaped and double spur cordon training systems, it was observed that BRS Violeta cultivar also produced bunches of higher fresh weight, with values of 192.5 and $186.2 \mathrm{~g}$, respectively. Bordô cultivar, similar to the VSP training system, produced bunches of smaller weight, 100.8 and $102.4 \mathrm{~g}$, respectively for Y and CD. For Isabel, Isabel Precoce and Concord cultivars, intermediate values were obtained for $Y$ and $C D$ systems, ranging from $122.5 \mathrm{~g}$ for Isabel Precoce in double spur cordon to $153.3 \mathrm{~g}$ for Concord in Y-shaped training system. Values reported by Pedro Júnior et al. (2017) for Isabel Precoce cultivar in Y-shaped training system, in the region of Louveira-SP, were similar to those obtained in this study.

Number of bunches- The number of bunches per plant (Table 1) in the VSP training system was lower for BRS Violeta cultivars followed by Bordô, respectively, with 16.8 and 23.2 bunches per plant. Isabel Precoce, Isabel and Concord cultivars presented the highest values of number of bunches, varying between 27 and 29. For Isabel and BRS Violeta cultivars in the VSP training system, Ribeiro et al (2013) observed respectively 23.5 and 19.8 bunches per plant, also verifying that BRS Violeta cultivar produced smaller number of bunches compared to Isabel cultivar.

For $\mathrm{Y}$ and $\mathrm{CD}$ training systems that allow obtaining greater number of bunches per plant, it was verified that BRS Violeta cultivar had the lowest values, respectively 22.6 and 31.7, followed by Bordô cultivar, with 31.6 and 43.5 bunches per plant. Isabel, Isabel Precoce and Concord cultivars presented higher number of bunches per plant, varying between 40 and 50, depending on the cultivar and training system. For training systems that allow higher yield of bunches per plant such as Geneva Double Curtain (GDC), different authors observed higher values such as 74 bunches per plant for 'Isabel' in GDC in Northern state of Paraná (SATO et al. 2009), and 97.7 bunches per plant for Concord cultivar supported on horizontal overhead system (pergola) in the region of Rolândia-PR (BORGES et al., 2014).

Yield - In the VSP system, Bordô and BRS Violeta cultivars presented lower values, respectively 10.75 and $13.69 \mathrm{tha}^{-1}$, statistically differing from the other cultivars evaluated. The values observed for 'Bordô' were similar to those reported by Mota et al. (2009) for Caldas-MG, who point out that it was the rainy years influenced the high yields obtained. For BRS Violeta cultivar, Ribeiro (2013) reports for Jundiaí-SP productivity up to $18 \mathrm{tha}^{-1}$, higher than that obtained in this work.

In the Y-shaped training system, Isabel and 
Concord cultivars showed higher average yield values, which differed statistically from the other cultivars. Yield was higher than $30 \mathrm{t} \mathrm{ha}^{-1}$ whereas in the CD system, except for the Bordô cultivar, no difference was observed comparing the average yields of Isabel Precoce, BRS Violeta, Isabel and Concord cultivars.

Yields obtained in the VSP system for Isabel cultivar were similar to values reported by Santos et al. (2011) and Hernandes et al. (2010). While yields observed in the $\mathrm{CD}$ and $\mathrm{Y}$ systems were higher than those reported for 'Isabel' in GDC training system (SATO et al., 2009), since the author used larger spacing, obtaining estimated yields of $18.7 \mathrm{t} \mathrm{ha}^{-1}$. BRS Violeta cultivar showed high productivity in the $\mathrm{CD}$ system because it compensates the low number of bunches produced by vines by the greater bunch fresh weight. Yield values for 'Concord' observed in this study were higher than those reported by Borges et al. (2014) for vines trained in pergola $\left(10.9 \mathrm{t} \mathrm{ha}^{-1}\right)$ in Rolândia - PR.

Regarding the 'Isabel Precoce' in the Y-shaped training system, values that did not statistically differ from BRS Violeta cultivar were obtained, respectively 23.06 and $22.04 \mathrm{t} \mathrm{ha}^{-1}$. These values were similar to those reported by Pedro Júnior et al. (2017) for Isabel Precoce cultivar in Y system $\left(19.46 \mathrm{t} \mathrm{ha}^{-1}\right)$ in the region of Louveira-SP.

Soluble solids content (SS) - The comparison of the average soluble solids content showed that the highest SS values, 18.3 and $18.5^{\circ}$ Brix, respectively, were obtained in the VSP system for Isabel and Isabel Precoce cultivars, compared to other cultivars. Values obtained for Isabel cultivar in VSP training system were higher than those observed in northern Paraná (ASSIS et al., 2011), Serra Gaúcha (RIZZON and MIELE, 2006); Caldas (PEREIRA et al., 2008) and Muzambinho, in Minas Gerais (APARECIDO et al., 2017). Bordô cultivar showed the lowest soluble solids content (15.1 $\left.{ }^{\circ} \mathrm{Brix}\right)$, similar to values reported by Chiarotti (2011) for Bocaiuva do Sul-RS and lower than those observed by Pereira et al. (2008) in Caldas-MG. BRS Violeta and Concord cultivars presented intermediate values, respectively 17.2 and 16.9 ${ }^{\circ}$ Brix, higher than those observed for 'Concord' cultivated in Eldorado do Sul (ANZANELLO et al. 2008) and Caldas-MG (PEREIRA et al. al., 2008). For BRS Violeta cultivar, Aparecido et al. (2017) observed, even during the winter season, total soluble solids content of $15.7^{\circ} \mathrm{Brix}$, while Silva et al. (2017) reported value of $18.4^{\circ}$ Brix for 'BRS Violeta' in the region of Jundiaí-SP.

In the $\mathrm{CD}$ and $\mathrm{Y}$ training systems, only 'Bordô' showed SS values lower than the other cultivars, that is, respectively, 14.6 and $15.1{ }^{\circ} \mathrm{Brix}$. In the Y-shaped system, Isabel Precoce, BRS Violeta, Isabel and Concord cultivars did not statistically differ from each other, with values of $16.7 ; 16.7 ; 17.3 ; 16.9{ }^{\circ}$ Brix, respectively. In the CD training system, no statistical difference was observed between Isabel Precoce and Isabel cultivars, which presented the highest soluble solids content, respectively 17.7 and $17.6^{\circ}$ Brix, while for BRS Violeta and Concord cultivars, which did not show averages differing statistically, values were 16.5 and $16.7^{\circ}$ Brix. For training systems with higher number of bunches, Borges et al. (2014) observed soluble solids content of $12.4^{\circ}$ Brix for Concord cultivar in pergola; Ribeiro et al. (2012) of $21.0^{\circ}$ Brix for Isabel Precoce cultivar in trellis system and Sato et al., (2009) $16.7^{\circ}$ Brix for Isabel cultivar in the Geneva Double Curtain system. Values obtained by Ribeiro et al. (2012) were higher because vines were cultivated in Petrolina-PE, where water and thermal conditions, favor the accumulation of sugars in grapes. However, the differences found by the various authors are probably due to the climatic differences among production sites and harvest year, because when grape maturation and harvest coincides with a less rainy period, the process is favored, allowing greater accumulation of sugars in grapes (SANTOS et al., 2011; REGINA et al., 2011).

Titratable acidity (TA) - In the VSP system, it was verified that the Bordô cultivar presented the highest TA value ( $\left.95.7 \mathrm{mEq} \cdot \mathrm{L}^{-1}\right)$, statistically differing from the other cultivars. For Bordô cultivar in VSP system, other authors obtained lower values, in Bocaiuva do Sul-RS (CHIAROTTI et al., 2011) and Caldas-MG (MOTA et al., 2009). The lowest TA value was observed for 'Concord' ( $\left.58.5 \mathrm{mEq} \cdot \mathrm{L}^{-1}\right)$, which was lower than that observed by Anzanello et al. (2008) in Eldorado do Sul-RS and Pereira et al. (2008) in Caldas-MG. Isabel Precoce, Isabel and BRS Violeta cultivars showed TA values between 67 and $84 \mathrm{mEq} \cdot \mathrm{L}^{-1}$.

For $\mathrm{Y}$ and $\mathrm{CD}$ training systems, the statistical differences between the mean TA values for cultivars were not observed, except for 'BRS Violeta' in the Y system and Concord cultivar in the $\mathrm{CD}$ system. TA values ranged from 64 to $81.5 \mathrm{meq} \cdot \mathrm{L}^{-1}$ for the Y-shaped trellis system and from 60.5 to $81 \mathrm{meq} \mathrm{L}^{-1}$ for the CD system. In northern Parana, Sato et al. (2009) observed lower values, $50 \mathrm{mEq} \cdot \mathrm{L}^{-1}$, for Isabel cultivar in GDC system and in Rolândia-PR, Borges et al. (2014) obtained values of $78 \mathrm{mEq} \cdot \mathrm{L}^{-1}$ for Concord cultivar in pergola system.

Maturation index - It was verified that the relationship between total soluble solids (SS) and tartaric acid content (TAC) for cultivars evaluated in the VSP system were higher for Concord (39.5) and Isabel cultivars (38.0), while the lowest values were observed for Bordô (25.0) and BRS Violeta cultivars (27.7). These values were higher than those reported for Isabel cultivar by Pereira et al. (2008) and for Concord cultivar by Anzanello et al. (2008). In the Y-shaped system, only BRS Violeta cultivar had lower mean value (28.0) and statistically 
different from other cultivars (averages of 34-36). In the CD system, similar to VSP, Bordô and BRS Violeta cultivars were those with the lowest SS / TAC value, 26.8 and 29.0 respectively. The other cultivars showed values higher than 33. For training systems with higher productivity, Borges et al. (2014) obtained values of 16.7 for Concord cultivar and Sato et al (2009) observed for Isabel cultivar in pergola, value of 38.8, similar to Pedro Júnior et al. (2017) for 'Isabel Precoce' in Y-shaped trellis, whose value was 46.6 .

Principal Component Analysis - principal components analysis was carried out to characterize the productive behavior of cultivars in the different training systems. According to the principal components analysis of production parameters, data variability could be explained in the first two main components, with $96.59 \%$.
Principal component 1 (Table 2) is associated with number of branches (NR), number of bunches (NC) and productivity (Prod). Component 2 is associated with fresh bunch weight (MFC). In the principal component analysis graph (Figure 1), it could be observed that all cultivars in VSP system showed smaller number of bunches and number of branches and, consequently, lower productivity. Lower yield value for BRS Violeta cultivar in Y system due to the lower number of bunches was also observed (Table 2 and Figure 1). Bordô cultivar in Y system also showed lower productivity due to the lower bunch fresh weight. In addition, higher MFC average values were observed for BRS Violeta cultivar in the different training systems. In general, PCA showed that $Y$ and CD training systems were associated with higher yields for cultivars evaluated, except for BRS Violeta and Bordô in Y-shaped training system.

Table 1. Averages of phytotecnical variables of vines and physicochemical characteristics of grape must for grape cultivars in different training systems.

\begin{tabular}{|c|c|c|c|c|c|c|c|c|}
\hline $\begin{array}{c}\text { Training } \\
\text { system }\end{array}$ & Cultivar & $\begin{array}{c}\text { Bunch } \\
\text { weight (g) }\end{array}$ & $\begin{array}{c}\text { Number of } \\
\text { bunches }\end{array}$ & $\begin{array}{c}\text { Number of } \\
\text { branches }\end{array}$ & $\begin{array}{c}\text { Yield } \\
\left(\mathrm{t} \mathrm{ha}^{-1}\right)\end{array}$ & $\begin{array}{l}\text { Soluble } \\
\text { solids } \\
\left({ }^{\circ} \text { Brix }\right)\end{array}$ & $\begin{array}{l}\text { Titratable } \\
\text { acidity } \\
\left(\mathrm{mEq} \cdot \mathrm{L}^{-1}\right)\end{array}$ & $\begin{array}{l}\text { Maturation } \\
\text { index }\end{array}$ \\
\hline \multirow{5}{*}{ VSP } & Isabel Precoce & $117.4 \mathrm{~cd}$ & $28.4 \mathrm{a}$ & $17.6 \mathrm{a}$ & $16.63 \mathrm{~b}$ & $18.5 \mathrm{a}$ & $76.5 \mathrm{bc}$ & $33.9 \mathrm{~b}$ \\
\hline & Bordô & $93.3 \mathrm{~d}$ & $23.2 \mathrm{~b}$ & $17.4 \mathrm{a}$ & $10.75 \mathrm{~d}$ & $15.1 \mathrm{c}$ & $95.7 \mathrm{a}$ & $25.0 \mathrm{c}$ \\
\hline & BRS Violeta & $164.1 \mathrm{a}$ & $16.8 \mathrm{c}$ & $16.4 \mathrm{a}$ & $13.69 \mathrm{c}$ & $17.2 \mathrm{~b}$ & $84.0 \mathrm{~b}$ & $27.7 \mathrm{c}$ \\
\hline & Isabel & $126.0 \mathrm{bc}$ & $28.5 \mathrm{a}$ & $16.9 \mathrm{a}$ & $17.70 \mathrm{ab}$ & $18.3 \mathrm{a}$ & $67.0 \mathrm{~cd}$ & $38.0 \mathrm{ab}$ \\
\hline & Concord & $148.4 \mathrm{ab}$ & $27.1 \mathrm{a}$ & $17.1 \mathrm{a}$ & $19.61 \mathrm{a}$ & $16.9 \mathrm{~b}$ & $58.5 \mathrm{~d}$ & $39.5 \mathrm{a}$ \\
\hline \multirow{5}{*}{ Y } & Isabel Precoce & $126.7 \mathrm{c}$ & $37.8 \mathrm{~b}$ & $21.3 \mathrm{~b}$ & $23.06 \mathrm{~b}$ & $16.7 \mathrm{a}$ & $64.0 \mathrm{~b}$ & $35.6 \mathrm{a}$ \\
\hline & Bordô & $100.8 \mathrm{~d}$ & $31.6 \mathrm{c}$ & $18.7 \mathrm{c}$ & $15.41 \mathrm{c}$ & $15.1 \mathrm{~b}$ & $66.5 \mathrm{~b}$ & $34.7 \mathrm{a}$ \\
\hline & BRS Violeta & $192.5 \mathrm{a}$ & $22.6 \mathrm{~d}$ & $18.3 \mathrm{c}$ & $22.04 \mathrm{~b}$ & $16.7 \mathrm{a}$ & $81.5 \mathrm{a}$ & $28.0 \mathrm{~b}$ \\
\hline & Isabel & $140.3 \mathrm{bc}$ & $44.7 \mathrm{a}$ & $26.2 \mathrm{a}$ & $30.58 \mathrm{a}$ & $17.3 \mathrm{a}$ & $67.3 \mathrm{~b}$ & $34.8 \mathrm{a}$ \\
\hline & Concord & $153.3 \mathrm{~b}$ & $40.1 \mathrm{ab}$ & $21.0 \mathrm{~b}$ & $29.09 \mathrm{a}$ & $16.9 \mathrm{a}$ & $66.0 \mathrm{~b}$ & $35.6 \mathrm{a}$ \\
\hline \multirow{5}{*}{$\mathrm{CD}$} & Isabel Precoce & $122.5 \mathrm{bc}$ & $53.3 \mathrm{a}$ & $28.1 \mathrm{a}$ & $31.87 \mathrm{a}$ & $17.7 \mathrm{a}$ & $72.0 \mathrm{a}$ & $33.6 \mathrm{ab}$ \\
\hline & Bordô & $102.4 \mathrm{c}$ & $43.5 \mathrm{~b}$ & $26.7 \mathrm{a}$ & $22.17 \mathrm{~b}$ & $14.6 \mathrm{c}$ & $81.0 \mathrm{a}$ & $26.8 \mathrm{c}$ \\
\hline & BRS Violeta & $186.2 \mathrm{a}$ & $31.7 \mathrm{c}$ & $27.0 \mathrm{a}$ & $29.39 \mathrm{a}$ & $16.5 \mathrm{~b}$ & $79.2 \mathrm{a}$ & $29.0 \mathrm{bc}$ \\
\hline & Isabel & $134.6 \mathrm{~b}$ & $50.6 \mathrm{ab}$ & $27.0 \mathrm{a}$ & $32.97 \mathrm{a}$ & $17.6 \mathrm{a}$ & $71.6 \mathrm{a}$ & $34.6 \mathrm{a}$ \\
\hline & Concord & $140.9 \mathrm{~b}$ & $47.4 \mathrm{ab}$ & $26.7 \mathrm{a}$ & $32.40 \mathrm{a}$ & $16.7 \mathrm{~b}$ & $60.5 \mathrm{~b}$ & $37.8 \mathrm{a}$ \\
\hline
\end{tabular}

*Means followed by the same letter in columns do not differ at the $5 \%$ level by the Tukey test within the same training system. $\mathrm{VSP}=$ vertical shoot position; $\mathrm{Y}=\mathrm{Y}$-shaped trellis, $\mathrm{CD}=\mathrm{V}$-shaped trellis with double spur cordon. 
Table 2. Eigenvalues and eigenvectors associated to the main components, relative (\%) and accumulated importance $(\%)$, referring to the productive characteristics of five grape cultivars in three training systems.

\begin{tabular}{ccccc}
\hline Variables & 1 & 2 & 3 & 4 \\
\hline MFC & -0.308 & 0.916 & 0.036 & 0.399 \\
NR & 0.585 & 0.008 & 0.809 & -0.048 \\
NC & 0.579 & -0.260 & -0.376 & 0.675 \\
Productivity & 0.567 & 0.307 & -0.449 & -0.619 \\
Eigenvalues & 2.676 & 1.188 & 0.128 & 0.008 \\
Difference & 1.488 & 1.060 & 0.119 & --- \\
Proportion (\%) & 66.89 & 29.69 & 3.20 & 0.21 \\
Accumulated (\%) & 66.89 & 96.59 & 99.79 & 100.00 \\
\hline
\end{tabular}

$\mathrm{MFC}=$ bunch fresh weight; $\mathrm{NR}=$ number of branches; $\mathrm{NC}=$ number of bunches;

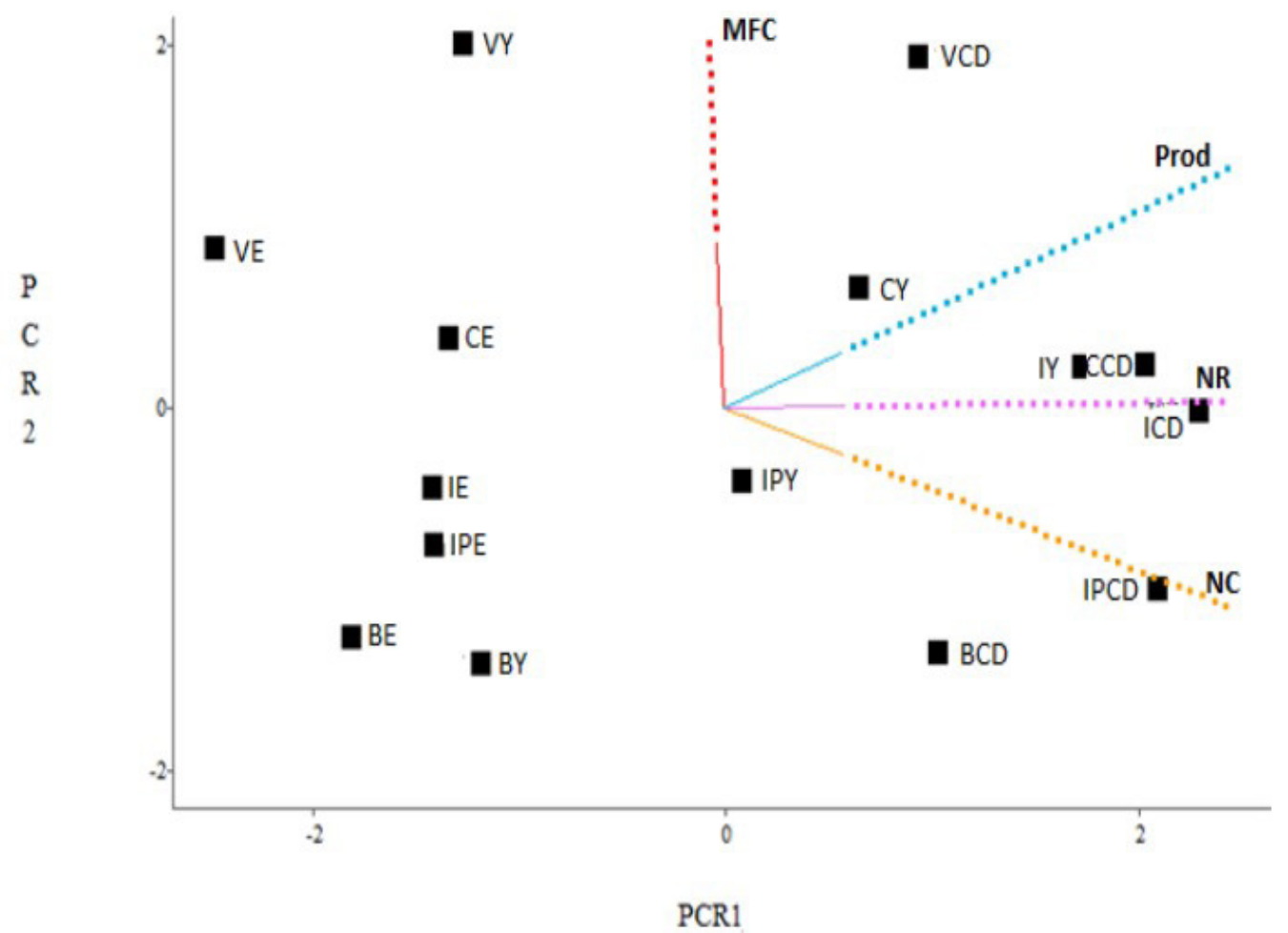

Figure 1. Principal component analysis with variables: bunch fresh weight (MFC), productivity (Prod), number of branches (NR) and number of bunches (NC) of five grape cultivars for juice and wine on three training systems. $\mathrm{B}=$ Bordô; IP=Isabel Precoce; V=BRS Violeta; $\mathrm{C}=$ Concord; $\mathrm{E}=\mathrm{VSP}-$ Vertical shoot position system; $\mathrm{Y}=\mathrm{Y}$-shaped trellis; $\mathrm{CD}=\mathrm{V}$-shaped trellis with double spur cordon.

\section{Conclusions}

BRS Violeta cultivar showed higher bunch fresh weight in the different training systems evaluated;

Isabel Precoce cultivar showed higher soluble solids content, regardless of training system;

Bordô cultivar showed lower productivity and soluble solids content;

The principal components analysis of production parameters allowed verifying that $\mathrm{Y}$-shaped and V-shaped trellis with double spur cordon training systems were associated with higher productivity.

\section{Acknowledgements}

To FAPESP (Project: 2013/10967-6) for the financial support to the research and $\mathrm{CNPq}$ for the Research Productivity Grant of the corresponding author (Proc. 302162/2016). 


\section{References}

ANZANELLO, R.; SOUZA, P.V.D.; GONZATTO, N.P. Produção de videiras 'Niagara Branca' e 'Concord' submetidas a duas safras por ciclo vegetativo na Depressão Central do Rio Grande do Sul. Scientia Agraria, Curitiba, v.9, n.3, p.311-316, 2008.

APARECIDO, L.E.O.; SILVA, R.E.B.; FRANCO JÚNIOR, K.S.; SOUZA, P.S.; ANGELOCCI, M.A. Ponto de maturação das cultivares de videiras Vitis labrusca L. na safra de inverno. Espacios, Caracas, v.38, n.22, p.36, 2017.

ASSIS, A.M.; YAMAMOTO, L.Y.; SOUZA, F.S.; BORGES, R.S.; ROBERTO, S.R. Evolução da maturação e características físico-químicas e produtivas das videiras 'BRS Carmem' e 'Isabel'. Revista Brasileira de Fruticultura, Jaboticabal, v.33, n.1, p.493-498, 2011. Número especial

BORGES, R.S.; ROBERTO, S.R.; YAMASHITA, F.; ASSIS, A.M.; YAMAMOTO, L.Y. Produção e qualidade de frutos de clones de videira 'Concord' sobre diferentes porta-enxertos. Pesquisa Agropecuária Tropical, Goiânia, v.44, n.2, p.198-204, 2014.

CAMARGO, E. A.; TONIETTO, J.; HOFFMANN, A. Progressos na viticultura brasileira. Revista Brasileira Fruticultura, Jaboticabal, v.33, n.1, p.144-149, 2011. Número especial

CAMARGO, U. A.; MAIA, J. D. G.; RITSCHEL, P. Embrapa Uva e Vinho: novas cultivares brasileiras de uva. Bento Gonçalves: Embrapa Uva e vinho, 2010. 64p.

CHAVARRIA, G.; CARDOSO, L.S.; BERGAMASCHI, H.; SANTOS, H.P.; MANDELLI, F; MARODIN, G.A.B. Microclima de vinhedos sob cultivo protegido. Ciência Rural, Santa Maria, v.39, p.2029-2034, 2009.

CHIAROTTI, F.; GUERIOS, I.T.; CUQUEL, F.L.; BIASI, L.A. Melhoria da qualidade de uva 'Bordô' para produção de vinho e suco de uva. Revista Brasileira de Fruticultura, Jaboticabal, v.33, n.1, p.618-624, 2011. Número especial

HERNANDES, J.L.; PEDRO JÚNIOR, M.J. 'Niágara Rosada': sistema de condução em Y e em cultivo protegido. Informe Agropecuário, Belo Horizonte, v.36, n.289, p.7-12, 2015.
HERNANDES, J.L.; PEDRO JÚNIOR, M.J.; SANTOS, A.O.; TECCHIO, M.A. Fenologia e produção de cultivares americanas e híbridas de uvas para vinho, em Jundiaí - SP. Revista Brasileira de Fruticultura, Jaboticabal, v.32, n.1, p. 135-142, 2010.

MOTA, R.V.; SOUZA, C.R.; FAVERO, A.C.; SILVA, C.P.C.; CARMO, E.L.; FONSECA, A.R.; REGINA, M.A. Produtividade e composição físico-química de bagas de cultivares de uva em distintos porta-enxertos. Pesquisa Agropecuária Brasileira, Brasília, DF, v.44, n.6, p. 576$582,2009$.

PEDRO JÚNIOR, M. J.; HERNANDES, J.L. Produtividade e qualidade do mosto de uva 'Isabel Precoce' em safras sequenciais de verão e inverno. Scientia Vitae, São Roque, v.5, n.5, p. 8-14, 2017.

PEDRO JÚNIOR, M.J.; HERNANDES, J.L.; ROLIM, G.S. Sistema de condução em Y com e sem cobertura plástica: efeitos no microclima, produção, qualidade do cacho e ocorrência de doenças fúngicas na videira 'Niagara Rosada'. Bragantia, Campinas, v.70, p.228233, 2011.

PEDRO JÚNIOR, M.J.; HERNANDES, J.L.; TECCHIO, M.A.; PEZZOPANE, J.R.M. Influência do sistema de condução no microclima, na produtividade e na qualidade de cachos da videira 'Niagara Rosada', em Jundiaí-SP. Revista Brasileira de Fruticultura, Jaboticabal, v.29, n.2, p.313-317, 2007.

PEREIRA, G.E.; LIMA, L.C.O.; REGINA, M.A.; ROSIER, J.P.; FERRAZ, V.; MOURÃO JÚNIOR, M. Avaliação do potencial de cinco cultivares de videiras americanas para sucos de uva no sul de Minas Gerais. Ciência e Agrotecnologia, Lavras, v.32, n.5, p.15311537,2008 .

REGINA, M.A.; MOTA, R.S.; FÁVERO, A.C.; SHIGA, T.M.; SILVA, L.H.J.; SOUZA, W.C.; NOVELLI, F.A.D.; SOUZA, C.R. Caracterização físico-química de uvas viníferas cultivadas em dupla-poda no nordeste de São Paulo. Revista Brasileira de Viticultura e Enologia, Bento Gonçalves, v.3, n.3, p.84-92. 2011.

RIBEIRO, F.L. Caracterização de cultivares de uvas para vinho sobre porta-enxertos, em Jundiaí-SP. 2013. 69 f. Dissertação (Mestrado) - Faculdade de Ciências Agronômicas, Universidade Estadual Paulista, Botucatu, 2013. 
RIBEIRO, T.P.; LIMA, M.A.C.; ALVES, R.E. Maturação e qualidade de uvas para suco em condições tropicais, nos primeiros anos de produção. Pesquisa Agropecuária Brasileira, Brasília, DF, v.47, n.8, p.1057-1065, 2012.

RIZZON, L.A.; MIELE, A. Efeito da safra vitícola na composição da uva, do mosto e do vinho Isabel da Serra Gaúcha, Brasil. Ciência Rural, Santa Maria, v. 36, n. 3, p.959-964, 2006.

SANTOS, A.O.; HERNANDES, J.L.; PEDRO JÚNIOR, M.J.; ROLIM, G.S. Parâmetros fitotécnicos e condições microclimáticas para a videira vinífera conduzida sob dupla poda sequencial. Revista Brasileira de Engenharia Agrícola e Ambiental, Campina Grande, v.15, n.12, p.1251-1256. 2011.

SATO, A.J.; SILVA, B.J.; SANTOS, C.E.; BERTOLUCCI, R.; GUIRAUD, M.C.; FONSECA, I.C.B.; ROBERTO, S.R. Evolução da maturação e características físicoquímicas de uvas da cultivar Isabel sobre diferentes portaenxertos na Região Norte do Paraná. Semina: Ciências Agrárias, Londrina, v.30, n.1, p.11-20, 2009.
SILVA, M.J.R.; VEDOATO, B.T.F.; LIMA, G.P.P.; MOURA, M.F.; COSER, G.M.A.G.; WATANABE, C.Y.; TECCHIO, M.A. Phenolic compounds and antioxidant activity of red and white grapes on different rootstocks. African Journal of Biotechnology, Nairobi, v.16, n.13, p.664-671, 2017.

TECCHIO, F. M.; MIELE, A.; RIZZON, L. A. Composição físico-química do vinho Bordô de Flores da Cunha, RS, elaborado com uvas maturadas em condições de baixa precipitação. Ciência Rural, Santa Maria, v.37, n.5, p.1480-1483, 2007.

VERDI, A.V.; OTANI, M.N.; MAIA, M.L.; FREDO, C.E.; OLIVEIRA, A.L.R.; HERNANDES, J.L. Panorama da vitivinicultura paulista, Censo 2009. Informações Econômicas, São Paulo, v.41, n.11, p.05-20, 2011. 